\title{
The faunal role in the degradation of the common intertidal salt marsh plant Scirpus maritimus
}

\author{
A. I. Lillebo $\cdot$ M. R. Flindt $\cdot$ M. A. Pardal • \\ P. G. Cardoso $\cdot$ S. M. Ferreira $\cdot$ J. C. Marques
}

Received: 10 February 2006/Revised: 23 October 2006/ Accepted: 11 November 2006/

Published online: 23 January 2007

(C) Springer Science+Business Media B.V. 2007

\begin{abstract}
The aim of this work was to evaluate the role of different environmental conditions (oxic and anoxic), and the presence of macrofauna and/or meiofauna during the different steps of Scirpus maritimus L. decomposition/mineralization under controlled laboratory conditions. The results showed no significant differences between the anaerobic and the aerobic degradation of plant material, under the presence of bacteria or meiofauna. Nevertheless, under anoxic conditions sediment mineralization was enhanced, with an increase concentration of phosphorus and ammonium in the water phase. Concerning the presence of fauna, results show that, although bacterial activity was responsible
\end{abstract}

Handling editor: S. M. Thomaz

A. I. Lilleb $\varnothing(\square)$

CESAM - Centre for Environment and Marine

Studies, Department of Chemistry, University of

Aveiro, Campus Universitário de Santiago, 3810-193

Aveiro, Portugal

e-mail: lillebo@dq.ua.pt

A. I. Lilleb $\varnothing \cdot$ M. A. Pardal

P. G. Cardoso · S. M. Ferreira · J. C. Marques

IMAR - Institute of Marine Research, Department of

Zoology, University of Coimbra, 3004-517 Coimbra,

Portugal

M. R. Flindt

Institute of Biology, SDU - University of Odense,

Campusvej 55, 5230 Odense M, Denmark for $70 \%$ of the S. maritimus leaves degradation, the presence of macrofauna together with meiofauna enhanced the leaves mineralization up to $90 \%$. Moreover, the presence of macrofauna together with meiofauna significantly affected the decomposition of phosphorus and of nitrogen, as well as the leaves lesser labile structural parts, by increasing the mineralization of plant carbon, and raised the nutrient turnover within the system. The present study reinforces the functional link between fauna levels on the nutrient dynamics in salt marshes ecosystems, namely at the vegetation detritus/water column interface.

Keywords Scirpus maritimus - Decomposition · Mineralization · Litter · Fauna

\section{Introduction}

Salt marshes are usually organized and ruled by a small set of dominant animals and plants that, together with the abiotic processes, structure the substrate and condition the functioning of the system at different scales (Widdows \& Brinsley, 2002). By having high organic productivity, salt marshes enhance secondary production and, in these ecosystems, the organic detritus/decomposition pathway represents the basic source that maintains the abundance and productivity of benthic invertebrates (e.g. Raffaelli, 1992; Dol- 
beth et al., 2003). Scirpus maritimus L. is widely distributed in European and North American marshes (Peláez et al., 1998) but knowledge about the production, degradation and ecological implications is scarce. Scirpus maritimus has stoutly rhizomatous perennial sedge, with photosynthetic shoots active for a single growing season (Karagatzides \& Hutchinson, 1991; Charpentier \& Stuefer, 1999; Lillebø et al., 2003), and usually forms similar dense monospecific stands in shallow brackish marshes during spring/summer (Lieffers \& Shay, 1982; Lillebø et al., 2003). In the Mondego estuary, a shallow warm-temperate estuary on the Atlantic coast of Portugal $\left(40^{\circ} 08^{\prime} \mathrm{N}, 8^{\circ} 50^{\prime} \mathrm{W}\right)$, this species has a particular above-ground life cycle with a growing season from January to April/May (Lillebø et al., 2003). In this system, the senescence phase of Scirpus occurs in June/July while the fauna and the heterotrophic microbial decomposers are highly active, which is reflected in an increase of secondary production (Dolbeth et al., 2003), and this potentially should favour a faster and more complete degradation of the plant detritus. Therefore, the aim of this study was to measure decomposition dynamics and rates of newly senescent Scirpus leaves and roots in a laboratory set-up under controlled oxygen and temperature conditions. The experiment was performed to evaluate the effect of macrofauna, meiofauna and bacteria on the decomposition rates, and included the measurements of carbon, nitrogen and phosphorus concentrations in the water phase and in the plant tissue.

\section{Materials and methods}

Adult plants, estuarine water, sediment, and macrofauna were collected in Mondego estuary (for a more detailed description see Lilleb $\varnothing$ et al., 2003) and brought to the laboratory. The experimental set-up included twelve sub-experiments (Fig. 1) that were performed in small glass con-

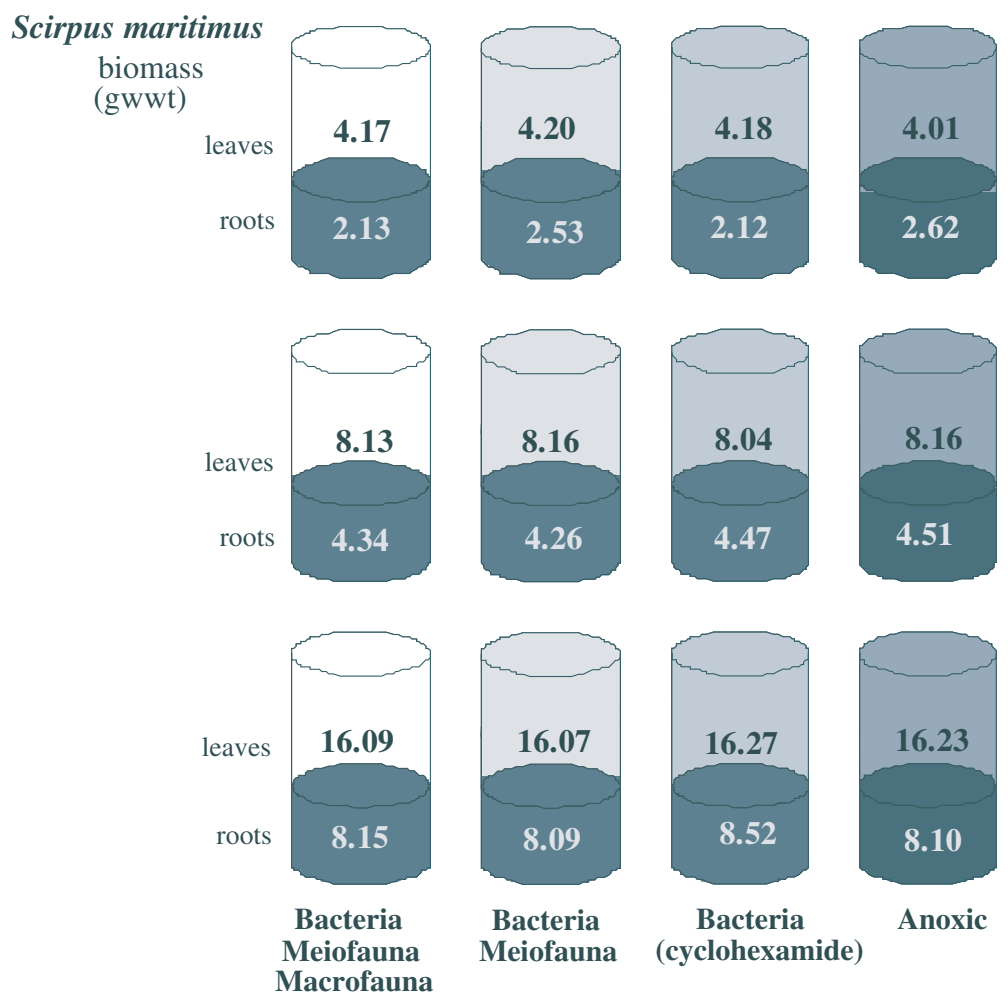

Fig. 1 The randomized block experimental design for Scirpus maritimus mineralization, corresponding to 4 treatments ( 3 fauna levels under oxic conditions and 1 anoxic condition) and 3 blocks (initial plant biomass) 
tainers of $31(\varnothing: 14.0 \mathrm{~cm})$. Each glass contained about $1 \mathrm{~kg}$ (wwt) sediment, sieved through a $1 \mathrm{~mm}$ mesh size to restrict infauna variability and mixed to improve the homogeneity among containers, and 2.51 of GF/F filtered estuarine water. $S$. maritimus wet weight (g wwt) above ground material was placed on the sediment surface, while roots were buried at $3 \mathrm{~cm}$ depth. Macrofauna representing field mean densities (Dolbeth et al., 2003; Cardoso et al., 2004) was composed of Scrobicularia plana (Da Costa), Nereis diversicolor L., Hydrobia ulvae (Pennant) and Cyathura carinata (Krøyer). The initial biomass was calculated in ash free dry weight (g AFDW) and the mean value per glass container corresponded to $0.30 \mathrm{~g}$ S. plana, $1.99 \mathrm{~g} \mathrm{~N}$. diversicolor, $1.88 \mathrm{~g} \mathrm{H}$. ulvae and $0.63 \mathrm{~g} \mathrm{C}$. carinata. To calculate the macrofauna initial biomass in ash free dry weight (g AFDW), the sorted specimens were measured $(\mathrm{mm})$ or weighed ( $\mathrm{g}$ wwt-wet weight), according to previous established length-weight relationships (Lilleb $\varnothing$ et al., 1999a; Ferreira et al., 2004; Verdelhos et al., 2005).

The experimental design included the method of randomized complete blocks, a type of twoway ANOVA without replication, in which Scirpus maritimus biomass constitutes the blocks (Fig. 1). With this laboratory set-up, high tide conditions were simulated and the anaerobic and the aerobic degradation of plant material and sediment organic matter was assessed. The aerobic containers were kept oxic by gentle bubbling with atmospheric air. In the anaerobic experimental setup, a lid covered the container and ensured that anoxic conditions developed within the first 2 days of the experiment. The sieved and well-mixed sediment in all containers was assumed to contain the same biomass of bacteria and meiofauna. Macrofauna was added into the containers that should represent all fauna levels. In containers that only represented the bacterial degradation of plant matter, the meiofauna was inactivated by adding the eucaryotic toxin cyclohexamide $\left(200 \mathrm{mg} \mathrm{l}^{-1}\right)$. The total experimental period was 57 days, and water samples were collected every 3 days for temporal resolution of the mineralization dynamics. Sub-samples of leaves and roots were used to analyze plant dry weight, loss on ignition $\left(3 \mathrm{~h}, 450^{\circ} \mathrm{C}\right)$ and $\mathrm{C}, \mathrm{N}$ and
$\mathrm{P}$ content. All water samples $(10 \mathrm{ml})$ were filtered $(\mathrm{GF} / \mathrm{F})$ and kept frozen until analysis. The removed water was replaced with filtered estuarine water with known concentrations of nutrients. Sediment triplicate sub-samples were analyzed for dry weight, loss on ignition $(8 \mathrm{~h}$, $450^{\circ} \mathrm{C}$ ), total nitrogen and phosphorus.

At the end of the experiment, the macrofauna was carefully sorted from the sediment $(1 \mathrm{~mm}$ mesh sieve) and the biomass quantified in ash free dry weight ( $\mathrm{g}$ AFDW). Analysis for dissolved reactive phosphate, ammonia and nitrate were carried out in a rapid flow auto analyser (RFA 300 Alpkem) and performed according to Alpkem methodologies (Alpkem, 1990). Samples for DOC were GF/F filtered, acidified $(2 \mathrm{~N} \mathrm{HCl})$ and kept frozen until analysis on a Shimadzu TOC-5000. Before elementary analyses all plant material was dried to constant weight at $105^{\circ} \mathrm{C}$, and analyzed for carbon and nitrogen content (CHN-analyser, Carlo Erba), while total phosphorus was determined according to Limnologisk Metodik (1992). Organic carbon in the sediment was estimated as $40 \%$ mass of the loss on ignition $\left(8 \mathrm{~h}, 450^{\circ} \mathrm{C}\right)$. Experimental conditions were kept until Scirpus maritimus mineralization corresponded to $90 \%$ of mass loss. The significant differences between treatments were determined using a randomized block analysis of variance, which is a type of two-factor analysis of variance without replication (Zar, 1996). Whenever the $F$-value for a factor turned out significant, it was applied the post hoc Tukey's Honestly Significant Difference test for the multiple comparisons (Zar, 1996). For the time series, the analysis of variance was performed using a general linear model (GNL-STATISTICA 6.0 software package). A model for repeated-measures analysis of variance, in which the subjects corresponded to factor A (treatments), factor B (time) and blocks (Scirpus maritimus biomass) were entered as covariate.

\section{Results}

The general linear model for repeated-measures analysis of variance showed that in the water phase there were no significant differences concerning the Scirpus maritimus blocks effect, 
except for the phosphate results in which the blocks effect and the interaction between time and blocks was significant $(P<0.05$; Table 1$)$. The treatments (factor A) was always significantly different $(P<0.001$ for phosphate, ammonia and nitrate) as well as the interaction between treatments and time $(\mathrm{A} \times \mathrm{B}) \quad(P<0.001$ for phosphate, ammonia and nitrate; Table 1). Considering carbon (DOC), no significant differences were found among subjects (Covariate-blocks; Factor $\mathrm{A}$-treatments and S/A-error) or within subjects (Factor $\mathrm{B}$-time; $\mathrm{B} \times$ Covariate; $\mathrm{B} \times \mathrm{A}$ and $\mathrm{B} \times \mathrm{S} / \mathrm{A}$-error; Table 1 ).

In the water phase, differences in dissolved inorganic nutrients concentrations were higher between anoxic and oxic conditions than between treatments under oxic conditions, except for carbon were no significant differences were found (Fig. 2). The increase of phosphate in the water phase under anoxic conditions was probably a partial result of desorption from the reduced iron sites in the sediment pool. Regarding nitrogen (ammonia and nitrate) in the water-phase (Fig. 2b, c), results show that under anoxic conditions, all mineralized nitrogen was re-found as an increase in the ammonia pool. During the first days, the DOC concentrations were quite similar among treatments, and it seems that, after this period, DOC was released from the sediment pool (Fig. 2d). Although, the DOC concentrations in the water phase seem to fluctuate through time, no significant differences were found between treatments, concerning fauna levels or oxic conditions.

The randomized block analysis of variance (Table 2) showed that there are significant differences among treatments during leaves mineralization. At the end of the experimental period (57 days), the oxic degradation of Scirpus maritimus leaves was higher in the presence of bacteria, meiofauna and macrofauna $(91.1 \% \pm$ 1.4 , loss of the initial biomass, mean value between blocks $\pm \mathrm{SE}, n=3$ ) comparatively to both the oxic experiments in which meiofauna and bacteria $(77.9 \% \pm 3.5)$, or only bacteria $(75.36 \pm 2.6)$ were present, and to the anoxic experiment $(79.56 \% \pm 4.4)$, (Fig. 3). The post hoc Tukey's Honestly Significant Difference test, for the multiple comparisons showed that the first

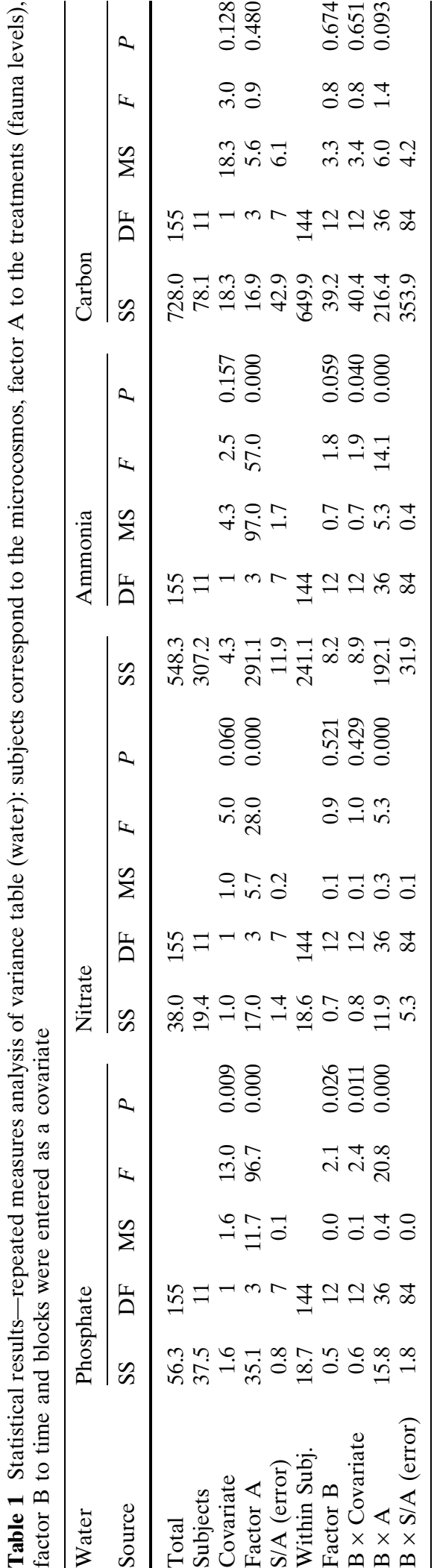



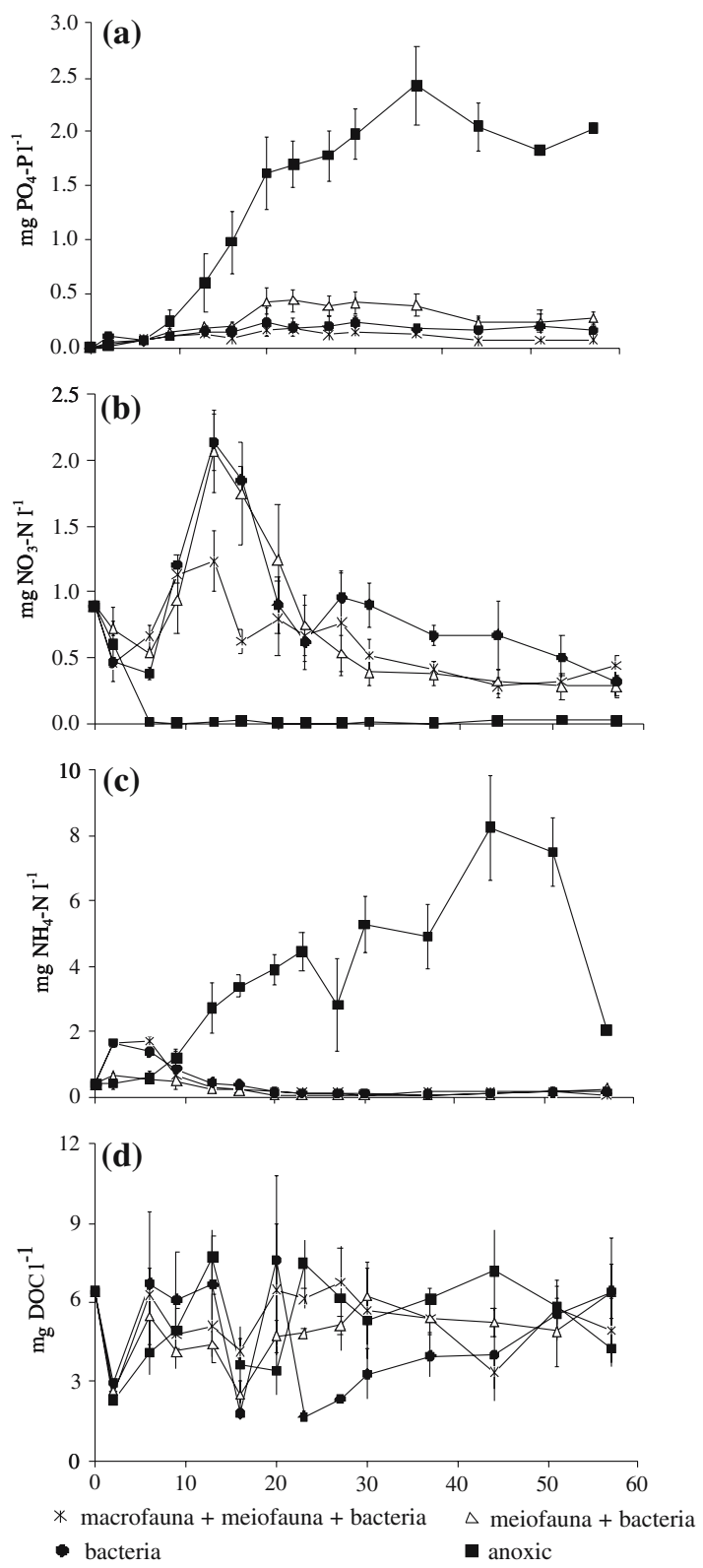

Fig. 2 Dissolved inorganic nutrients in the water-phase (mean value for each block $\pm \mathrm{SE}, n=3$ ). (a) Phosphate, (b) Nitrate, (c) Ammonia, (d) Carbon (DOC)

treatment was significantly different from the others (Fig. 3).

Considering roots mineralization, although the highest degradation in biomass occurred when only bacteria were present under oxic conditions (67.94 \pm 2.3 ), (Fig. 3), no significant differences were found between the different fauna levels or oxic state in view of the randomized block analysis of variance.

For the $\mathrm{C}, \mathrm{N}$ and $\mathrm{P}$ mineralization in leaves, the randomized block analysis of variance (Table 2) showed that there are significant differences among fauna levels. The highest carbon, nitrogen and phosphorus mineralization of leaves occurred when macrofauna, meiofauna and bacteria were present, and the post hoc analysis showed that this treatment was significantly different from the others (Fig. 4). In leaves (mean value between blocks) $86 \% \mathrm{C} \pm 8.9 \mathrm{SE}, 88 \% \mathrm{~N} \pm 6.8 \mathrm{SE}$ and $95 \% \mathrm{P} \pm 0.6 \mathrm{SE}$ was mineralized (Fig. 4). During roots mineralization, no significant differences were found between the fauna groups, despite mineralization of $\mathrm{P}>\mathrm{C}>\mathrm{N}$ (Fig. 4). The analysis of the $\mathrm{C}: \mathrm{N}$ ratio in leaves and roots (Table $3 \mathrm{~A}$ ) during the degradation process did not show any significant differences among subjects (Covariateblocks; Factor A-fauna levels and S/A-error) or within subjects (Factor B-time; $\mathrm{B} \times$ Covariate; $\mathrm{B} \times \mathrm{A}$ and $\mathrm{B} \times \mathrm{S} / \mathrm{A})$. The results showed no significant differences between the anaerobic and the aerobic degradation of plant material, both in the presence of bacteria and meiofauna.

During the experimental period, the nutrient pool in the sediment (POM) was also mineralized, and the analysis of the $\mathrm{C}: \mathrm{N}$ and $\mathrm{N}: \mathrm{P}$ ratios during the degradation period show a similar dynamics for all treatments (Table 3B). No significant differences were found among subjects or within subjects, except for the interaction between time and treatments for sediment $\mathrm{N}: \mathrm{P}$ ratio $(\mathrm{B} \times \mathrm{A}$, $P<0.05)$.

During the first $10-15$ days, the N:P ratio in the water phase showed a very strong decrease, and remained low during the experimental period, while the C:N ratio increased especially after the first 10-15 days, except under anoxic conditions (Fig. 5).

\section{Discussion and conclusions}

In general, the degradation of plant litter is regulated not only by the concentrations of nutrients, but especially by the $\mathrm{C}: \mathrm{N}$ and $\mathrm{N}: \mathrm{P}$ ratios of plant material, and by the lability of carbon (Enriquez et al., 1993; Flindt et al., 1999). 
Table 2 Statistical results_randomized block analysis of variance table (Scirpus maritimus leaves)

\begin{tabular}{|c|c|c|c|c|c|c|c|c|c|c|c|c|}
\hline \multirow{3}{*}{$\begin{array}{l}\text { Scirpus maritimus leaves } \\
\text { Source of variation } \\
\text { Total }\end{array}$} & \multicolumn{3}{|c|}{ Biomass } & \multicolumn{3}{|c|}{ Carbon } & \multicolumn{3}{|c|}{ Nitrogen } & \multicolumn{3}{|c|}{ Phosphorus } \\
\hline & SS & DF & MS & SS & $\mathrm{DF}$ & MS & SS & DF & MS & SS & $\mathrm{DF}$ & MS \\
\hline & 320 & 11 & & 703 & 11 & & 577 & 11 & & 636 & 11 & \\
\hline Fauna le & 27 & 3 & 93 & 664 & 3 & 221 & 492 & 3 & 164 & 504 & 3 & 168 \\
\hline Blocks & 3 & 2 & & 29 & 2 & & 32 & 2 & & 78 & 2 & \\
\hline Remainder & 38 & 6 & 6 & 10 & 6 & 2 & 54 & 6 & 9 & 54 & 6 & 9 \\
\hline$F$ value & \multicolumn{3}{|c|}{ Но, $F=14.7$} & \multicolumn{3}{|c|}{ Но, $F=134.5$} & \multicolumn{3}{|c|}{ Но, $F=18.3$} & \multicolumn{3}{|c|}{$\mathrm{Ho}, F=18.8$} \\
\hline Critical value & \multirow{2}{*}{\multicolumn{3}{|c|}{$\begin{array}{l}F 0.05(1), 3,6=4.76 \\
P<0.005\end{array}$}} & \multirow{2}{*}{\multicolumn{3}{|c|}{$\begin{array}{l}F 0.05(1), 3,6=4.76 \\
P<0.0005\end{array}$}} & \multirow{2}{*}{\multicolumn{3}{|c|}{$\begin{array}{l}F 0.05(1), 3,6=4.76 \\
P<0.0025\end{array}$}} & \multirow{2}{*}{\multicolumn{3}{|c|}{$\begin{array}{l}F 0.05(1), 3,6=4.76 \\
P<0.0025\end{array}$}} \\
\hline Significance level & & & & & & & & & & & & \\
\hline
\end{tabular}

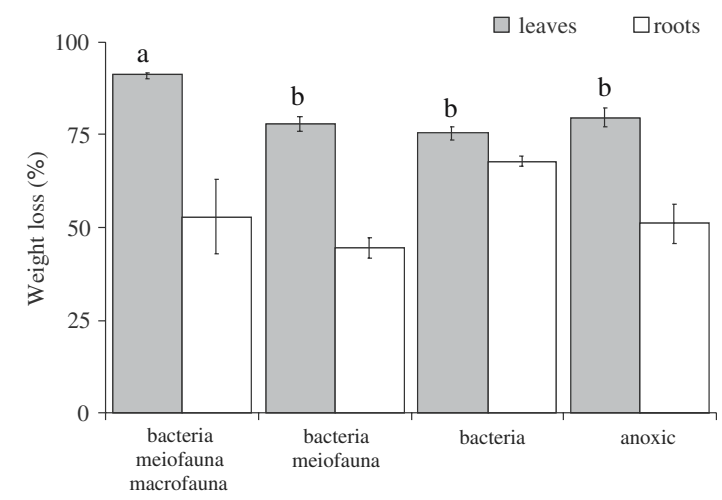

Fig. 3 Weight loss of Scirpus maritimus (mean value for each block \pm SE, $n=3$ ). The Tukey's test showed that the first treatment is significantly different from the others

A high initial $\mathrm{N}$ and $\mathrm{P}$ content is often related to higher mineralization rates, whilst a high content of structural compounds such as fibres is correlated with lower mineralization rates (Enriquez et al., 1993; Hill and Perrot, 1995; Wrubleski et al., 1997; Flindt et al., 1999).

Decomposition includes several different temporal phases that can be summarized in three steps: (I) initial leaching of easily degradable low molecular cellular substances, (II) intermediate decomposition of the structural parts, (III) slow degradation of the lesser labile structural parts (Godshalk \& Wetzel, 1978). Yet, each phase or the respective time length is not visible in the present study. In fact, in the water phase differences in dissolved inorganic nutrients concentrations were higher between environmental conditions (anoxic and oxic conditions) than between treatments under oxic conditions (presence macrofauna and/or meiofauna). In plant
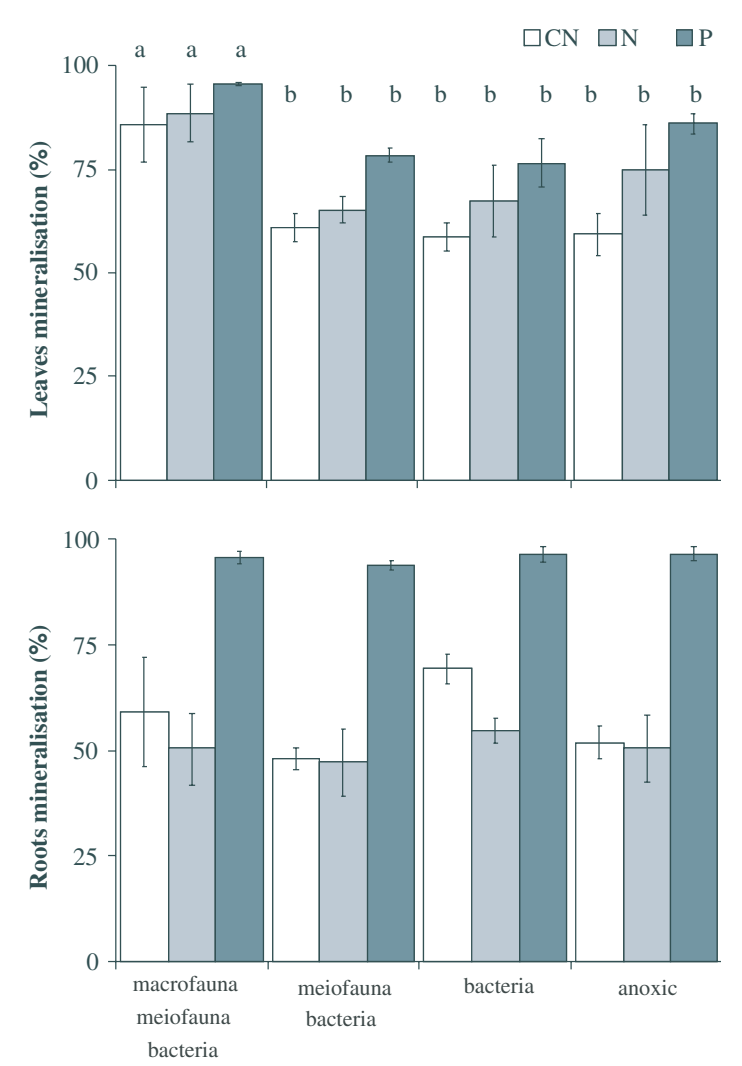

Fig. 4 Relative mineralization of Scirpus maritimus leaves and roots $\mathrm{C}, \mathrm{N}$ and $\mathrm{P}$ (mean value for each block $\pm \mathrm{SE}$, $n=3$ ). The Tukey's test showed that the first treatment is significantly different from the others

material, no significant differences were found concerning the $\mathrm{C}: \mathrm{N}$ ratio in leaves and roots during the degradation process, which probably occurred due to external factors. The increase concentration of phosphorus and ammonium in the water phase under anoxic conditions results 
Table 357 days of mineralization, in the presence of just bacteria (B), under oxic and anoxic conditions, bacteria and meiofauna $(\mathrm{Bm})$, and bacteria, meiofauna and mac- rofauna $(\mathrm{BmM})$ (mean value for each block $\pm \mathrm{SE}, n=3)$ : (A) Scirpus maritimus leaves and roots C:N ratios; (B) Sediment C:N and N:P ratios of the sediment

\begin{tabular}{|c|c|c|c|c|c|c|c|c|}
\hline \multirow[t]{2}{*}{ Day } & \multicolumn{2}{|l|}{$\mathrm{BmM}$} & \multicolumn{2}{|l|}{$\mathrm{Bm}$} & \multicolumn{2}{|l|}{ B } & \multicolumn{2}{|c|}{ Anoxic } \\
\hline & $\mathrm{C}: \mathrm{N}$ & SE & $\mathrm{C}: \mathrm{N}$ & SE & $\mathrm{C}: \mathrm{N}$ & SE & $\mathrm{C}: \mathrm{N}$ & SE \\
\hline \multicolumn{9}{|c|}{ (A) Leaves } \\
\hline 0 & 16.3 & & 16.3 & & 16.3 & & 16.3 & \\
\hline 13 & 23.3 & 3.7 & 18.6 & 1.5 & 14.2 & 1.3 & 14.4 & 0.6 \\
\hline 42 & 26.9 & 10.6 & 16.5 & 1.2 & 14.1 & 1.1 & 14.7 & 1.2 \\
\hline 57 & 23.9 & 2.8 & 18.4 & 1.8 & 21.0 & 1.8 & 22.3 & 5.2 \\
\hline \multicolumn{9}{|c|}{ (A) Roots } \\
\hline 0 & 47.2 & & 47.2 & & 47.2 & & 47.2 & \\
\hline 13 & 50.7 & 7.0 & 52.8 & 7.6 & 54.8 & 7.8 & 51.9 & 3.5 \\
\hline 42 & 42.3 & 3.3 & 50.1 & 9.6 & 22.2 & 3.0 & 43.4 & 1.4 \\
\hline 57 & 38.5 & 2.0 & 48.4 & 5.6 & 32.1 & 0.8 & 47.2 & 5.0 \\
\hline \multicolumn{9}{|c|}{ (B) Sediment } \\
\hline 0 & 13.0 & & 13.0 & & 13.0 & & 13.0 & \\
\hline 13 & 11.7 & 0.2 & 11.1 & 0.0 & 11.5 & 1.1 & 9.6 & 0.7 \\
\hline \multirow[t]{2}{*}{57} & 11.3 & 0.4 & 10.9 & 0.3 & 11.1 & 0.9 & 11.8 & 0.8 \\
\hline & $\mathrm{N}: \mathrm{P}$ & SE & $\mathrm{N}: \mathrm{P}$ & SE & $\mathrm{N}: \mathrm{P}$ & SE & $\mathrm{N}: \mathrm{P}$ & SE \\
\hline 0 & 3.3 & & 3.3 & & 3.3 & & 3.3 & \\
\hline 42 & 3.0 & 0.1 & 3.1 & 0.1 & 2.8 & 0.1 & 2.7 & 0.1 \\
\hline 57 & 2.8 & 0.1 & 2.9 & 0.1 & 2.8 & 0.2 & 3.4 & 0.2 \\
\hline
\end{tabular}
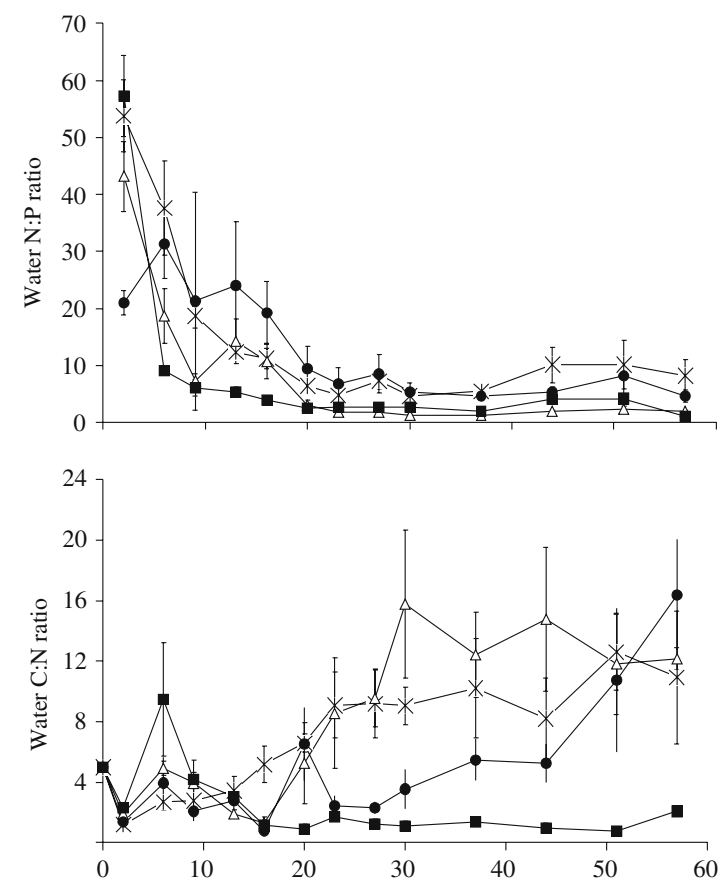

* macrofauna + meiofauna + bacteria $\Delta$ meiofauna + bacteria - bacteria anoxic

Fig. $5 \mathrm{~N}: \mathrm{P}$ and $\mathrm{C}: \mathrm{N}$ ratios in the water-phase (mean value for each block $\pm \mathrm{SE}, n=3$ ) from the sediment mineralization, and these results are in agreement with other studies showing that under anoxic conditions, and due to the organic matter degradation, large quantities of ammonia and phosphate are released from the sediment (Bonanni et al., 1992; Lillebø et al., 2002). In the oxic experiments, nitrate concentrations increased between the days 10-20, yet thought time the ammonification supplied the subsequent nitrification and denitrification, and hence, the mineralized nitrogen was transformed to $\mathrm{N}_{2}$ and lost. DOC concentrations in the water phase seem to fluctuate through time, and no significant differences were found between treatments. It has been observed elsewhere that DOM may flux into and out of the sediment, and that benthos can be a net source of DOC for the planktonic community in the water column (Hopkinson et al., 1998). Concerning the plant material, Morrisson (1989) verified, after temporal measurements, that litter had a lower C:N ratio due to heterotrophic bacteria colonization. On the other hand, Benner et al. (1997) found that the $\mathrm{N}$ content in decomposing Spartina tissues was highly variable, which was reflected in the wide range of $\mathrm{C}: \mathrm{N}$ values, and that a major fraction 
$(>50 \%)$ of the initial $\mathrm{N}$ in the tissue was lost during the early stages of decomposition, followed by the slow accumulation of exogenous $\mathrm{N}$.

No significant differences were found concerning the sediment $\mathrm{C}: \mathrm{N}$ and $\mathrm{N}: \mathrm{P}$ ratios during the degradation period. It has been shown that bacteria grow very rapidly in shallow water estuaries where efflux from the sediment dominates the dynamics in the water column (Hopkinson et al., 1998). The biogeochemical processes, conditioned by $\mathrm{N}$ and $\mathrm{P}$ mediating bacteria, primary producers, bioturbation activity and detritus feeders may change the sediment adsorption/desorption capacity and the nutrient budgets of these systems (e.g. Staver et al., 1996; Gilbert et al., 1998; Mitchell \& Baldwin, 1998; Widdows \& Brinsley, 2002).

The Scirpus maritimus mineralization rate of carbon, nitrogen and phosphorus in the experiments was significantly higher under aerobic conditions when bacteria, meiofauna and macrofauna were present. This indicates that the $\mathrm{C}, \mathrm{N}$ and P-turnover are higher when the macrofauna is contributing to the degradation. At the same time, it reinforces the link between fauna levels and the nutrient dynamics in salt marsh ecosystems. It seems that, although organic matter is primary degraded by micro-organisms, their presence enhances the nutritional quality of leaf litter for macroinvertebrates (Hill and Perrot, 1995). In addition, as summarized by DeMesel and others (2004), nematodes (meiofauna), by a direct effect of grazing on bacteria, by contributing to sediment bioturbation, to the physical breakdown of detritus and by excreting nutrients for bacteria, may stimulate detritus mineralization. Microcosmos experiments have suggested that, even at low densities, nematodes can have a significant structuring top-down influence on the bacteria growing on the cordgrass leaves detritus (DeMesel et al., 2004). Macrofauna may also feed directly on bacteria, and species such as Hydrobia ulvae, through their feeding activities on leaf surfaces (Barnes \& Hughes, 1988; Lillebø et al., 1999b), might contribute to the stimulation of microbial activity. Moreover, it has been shown that, in the presence of meiofauna, polychaetes can incorporate significantly more carbon from Zostera detritus (Tenore et al., 1977 in Valiela, 1995).
The degradation period of Scirpus maritimus leaves in the presence of macrofauna was faster than that observed for Spartina maritima under similar experimental conditions (Lillebø et al., 1999a). The degradation periods, estimated according to $90 \%$ of mass loss, were respectively 57 days and 99 days, while initial C:N ratio was 16 $(2.3 \% \mathrm{~N}$ and $38 \% \mathrm{C})$ and $16(2.5 \% \mathrm{~N}$ and $40 \%$ C). Although this seems contradictory, fast-growing plants tend to decompose quickly because of the adequacy of their litter as substrate for microbial growth (Enriquez et al., 1993). Spartina has a slow continuous growth (Adams \& Bate, 1995) and does not show a seasonal dieback (Benito \& Onaindia, 1991), while Scirpus photosynthetic shoots are active for a single growing season (Lillebø et al., 2003).

Macrofauna activity did not seem so important during the decomposition of roots, probably because most of the individuals belong to the epibenthic groups and roots were placed at $3 \mathrm{~cm}$ depth. In fact, it has been shown for other plant species that, in undisturbed marsh sediments, the major fate of below-ground production appears to be microbial decomposition (Benner et al., 1997), although the presence of meiofauna may also enhance the degradation (e.g. DeMesel et al., 2004).

It seems that the importance of fauna complexity increases though time, in the course of the three decomposition temporal phases, since carbon mineralization in Scirpus leaves was also significantly higher. This pattern of processing of Scirpus maritimus leaves is in agreement with the knowledge of litter processing in deciduous forest systems (Bunn, 1986). As stated by Enriquez and others (1993), decomposition of plant litter is mainly processed by bacteria and fungi, the rate of this process being dependent on all factors that condition their activity. On the other hand, Hill \& Perrotte (1995) considered microorganisms as the key catabolizers of leaf litter decomposition which simultaneously enriched the nutrient quality and palatability of litter for macroinvertebrate consumption, although both macrofauna and meiofauna may feed directly on bacteria (e.g. Barnes \& Hughes, 1988). Thus bacterial activity seems to be responsible for the initial leaching of easily degradable low molecular cellular substances. Yet, the presence of meiofauna and 
macrofauna enhances the intermediate decomposition of the structural parts and contributes to a faster degradation of the lesser labile structural parts, raising the nutrient turnover within the system.

Acknowledgements This study was carried out within the scope of the WET-project, (Wetland Ecology and Technology), funded by the European scientific TMR programme, (TMR) (ERB 4061 PL 95-0832) and by the Praxis programme (Portugal) through a $\mathrm{PhD}$ grant $(\mathrm{BD} /$ 9290/96). The authors would like to thank the Freshwater Biological Laboratory, University of Copenhagen, Denmark, for the technical support for this study. Special thanks go to Dr. P. Sousa for help on statistical data analysis.

\section{References}

Adams, J. B. \& G. C. Bate, 1995. Ecological implications of tolerance of salinity and inundation by Spartina maritima. Aquatic Botany 52: 183-191.

Alpkem, 1990. Rapid Flow Analyser-Methodology A303S202, A303-S170, A303-S020. ALPKEM Corporation, Clackamas, Oregon, USA.

Barnes, R. S. K. \& R. Hughes, 1988. An Introduction to Marine Ecology, 2nd edn. Blakwell Scientific Publications, Oxford, $351 \mathrm{pp}$.

Benito, I. \& M. Onaindia, 1991. Biomass and aboveground production of four angiosperms in Cantabrian ( $\mathrm{N}$. Spain) salt marshes. Vegetario 96: 165-175.

Benner, R., M. L. Fogel \& E. K. Sprague, 1997. Diagenesis of belowground biomass of Spartina alterniflora in salt marsh sediments. Limnology Oceanography 36: 13581374.

Bonanni, P., R. Caprioli, E. Ghiara, C. Migunzzi, C. Orlandi, G. Paganin \& A. Monti, 1992. Sediment and intertitial water chemistry of the Orbetello lagoon (Grosseto, Italy), nutrient diffusion across the watersediment interface. Hydrobiologia 235/236: 553-568.

Bunn, S. E., 1986. Origin and fate of organic matter in Australian upland streams. In De Deckker, P. \& W. D. Williams (eds), Limnology in Australia. CSIRO Australia, Melbourne, Dr. W. Junk Publishers, Dordrecht, 277-291.

Cardoso, P., M. A. Pardal, A. I. Lillebø, S. M. Ferreira, D. Raffaelli \& J. C. Marques, 2004. Dynamic changes in seagrass assemblages under eutrophication and implications for recovery. Journal of Experimental Marine Biology and Ecology 302: 233-248.

Charpentier, A. \& J. F. Stuefer, 1999. Functional specialization of ramets in Scirpus maritimus. Splitting the tasks of sexual reproduction, vegetative growth, and resource storage. Plant Ecology 141: 129-136.

DeMesel, I., S. Derycke, T. Mogens, K. Van der Gucht, M. Vincx \& J. Swings, 2004. Top-down impact of bacterivorous nematodes on the bacterial community structure: a microcosm study. Environmental Microbiology 6: 733-744.

Dolbeth, M., M. A. Pardal, A. I. Lilleb $\varnothing$, U. Azeiteiro \& J. C. Marques, 2003. Short term and long term effects of eutrophication on the secondary production of an intertidal macrobenthic community. Marine Biology 143:1229-1238.

Enriquez, E., C. M. Duarte \& K. Sand-Jensen, 1993. Patterns in decomposition rates among photosynthetic organisms: the importance of detritus C:N:P contend. Oecologia 94: 457-471.

Ferreira, S. M., M. A. Pardal, A. I. Lillebø, P. Cardoso \& J. C. Marques, 2004. Cyathura carinata population dynamics in a temperate eutrophic intertidal estuary. Estuarine, Coastal and Shelf Science 61: 669-677.

Flindt, M. R., M. A. Pardal, A. I. Lillebø, I. Martins \& J. C. Marques, 1999. Nutrient cycling and plant dynamic in estuaries: a brief review. Acta Oecologica 20: 237-248.

Gilbert, F., G. Stora \& P. Bonin, 1998. Influence of bioturbation on denitrification activity in Mediterranean coastal sediments: an in situ experimental approach. Marine Ecology Progress Series 163: 99107.

Godshalk, G. L. \& R. G. Wetzel, 1978. Decomposition of aquatic angiosperms. III. Zostera marina L. and conceptual model of decomposition. Aquatic Botany 5: 329-354.

Hill, B. H. \& W. T. Perrot Jr., 1995. Microbial colonization, respiration, and breakdown of maple leaves along a stream-marsh continuum. Hydrobiologia 312: 11-16.

Hopkinson, Jr., C. S., A. E. Giblin, R. H. Garritt, J. Tuker \& M. A. J. Hullar, 1998. Influence of the benthos on growth of planktonic estuarine bacteria. Aquatic Microbial Ecology 16: 109-118.

Karagatzides, J. D. \& I. Hutchinson, 1991. Intraspecific comparison of biomass dynamics in Scirpus americanus and Scirpus maritimus on the Fraser river delta. Journal of Ecology 79: 459-476.

Lieffers, V. J. \& J. M. Shay, 1982. Seasonal growth and standing crop of Scirpus maritimus var. paludosus in Saskatchewan. Canadian Journal of Botany 60:117125.

Lillebø, A. I., M. R. Flindt, M. A. Pardal \& J. C. Marques, 1999a. The effect of macrofauna, meiofauna and microfauna on the degradation of Spartina maritima detritus from a salt marsh area. Acta Oecologica 20: 249-258.

Lillebø, A. I., M. A. Pardal \& J. C. Marques, 1999 b. Population structure, dynamics and production of Hydrobia ulvae (Pennant) (Mollusca:Prosobranchia) along an eutrophication gradient in the Mondego estuary (Portugal). Acta Oecologica 20: 289-304.

Lillebø, A. I., M. R. Flindt, M. A. Pardal, I. Martins, J. M. Neto \& J. C. Marques, 2002. Nutrient dynamics in the intertidal pools of the Mondego estuary. II - Seasonal efflux of $\mathrm{PO}_{4}-\mathrm{P}$ and $\mathrm{NH}_{4}-\mathrm{N}$ in bare bottom and vegetated pools. In Pardal, M. A., J. C. Marques \& M. A. Graça (eds), Aquatic Ecology of the Mondego River Basin. Global Importance of Local Experience. 
Imprensa da Universidade de Coimbra, Coimbra, 257-272.

Lillebø, A. I., M. A. Pardal, J. M. Neto \& J. C. Marques, 2003. Salinity as the major factor affecting Scirpus maritimus annual dynamics. Evidence from field data and greenhouse experiment. Aquatic Botany 77: 111120.

Limnologisk Metodik, 1992. Ferskvandsbiologisk Laboratorium. Københavns Universitet (ed.). Akademisk Forlag, København, 172 pp.

Mitchell, A. \& D. S. Baldwin, 1998. Effects of desiccation/ oxidation on the potential for bacterial mediated $\mathrm{P}$ release from sediments. Limnology and Oceanography 43: 481-487.

Morrisson, P. G., 1989. Detrital processing in seagrass systems: a review of factors affecting decay rates, remineralisation and detritivory. Aquatic Botany 23: 263-288.

Peláez, F., J. Collado, F. Arenal, A. Basilio, A. Cabello, M. T. Díez Matas, J. B. García, A. González del Vale, V. González, J. Gorrochategui, P. Hernández, I. Martin, G. Platas \& F. Vicente, 1998. Endophytic fungi from plants living on gypsum soils as a source of secondary metabolites with antimicrobial activity. Mycology Research 102: 755-761.
Raffaelli, D., 1992. Conservation of Scottish estuaries. Proceedings of the Royal Society of Edinburgh 100B: $55-76$.

Staver, L. W., K. W. Staver \& J. C. Stevenson, 1996. Nutrients inputs to the Choptank River estuary: implications for watershed management. Estuaries 19: 342-358.

Valiela, I., 1995. Marine Ecological Processes, 2nd edn. Springer-Verlag, New York, Inc., 385-461.

Verdelhos, T., J. M. Neto, J. C. Marques \& M. A. Pardal, 2005. The effect of eutrophication abatement on the bivalve Scrobicularia plana. Estuarine, Coastal and Shelf Science 63: 261-268.

Widdows, J. \& M. Brinsley, 2002. Impact of biotic and abiotic processes on sediment dynamics and the consequences to the structure and functioning of the intertidal zone. Journal of Sea Research 48: 143-156.

Wrubleski, D. A., H. R. Murkin, A. G. Van der Valk \& J. W. Nelson, 1997. Decomposition of emergent macrophyte in the northern prairie marsh. Aquatic Botany 58: 121-134.

Zar, J., 1996. Biostatistical Analysis, 3rd edn. Prentice-hall International, Inc. Simon \& Schuster/A viacom Company, Upper Saddle River, N.J., USA, 250-254. 